\title{
PERANCANGAN ARSITEKTUR ENTERPRISE MENGGUNAKAN TOGAF FRAMEWORK (STUDI KASUS : CV. AGUNG LESTARI)
}

\author{
Andreas Perdana ${ }^{1}$, Suhendro Yusuf I, Ph.D ${ }^{2}$ \\ STMIK Dharmawacana Metro ${ }^{1}$ \\ Informatics \& Business Institute Of Darmajaya ${ }^{2}$
}

\begin{abstract}
C V$. Agung Lestari is a company engaged in services of new vehicle's documents. The company activities are using Information System (IS) and Information Technology (IT) and already have an application that used in Administration Division. However, in the absence of data integration and connection to information system between divisions. Unintegrated data allows for data redundancy, error, lack of data accuracy, and less efficient. Required a framework in planning, designing, and managing infrastructure called Enterprise Architecture(EA). The design in the form of System Administration, Finance Management System, Human Resource and Accounting. Data any information system is already integrated.
\end{abstract}

Keywords: Enterprise Architecture, TOGAF

\begin{abstract}
Abstrak: CV. Agung Lestari merupakan perusahaan yang bergerak di bidang jasa pengurusan suratsurat kendaraan baru. Perusahaan ini memanfaatkan SI/TI dalam aktifitas yang dilakukan dan sudah memiliki aplikasi yang digunakan pada bagian administrasi. Namun tidak ada integrasi data dan keterkaitan dengan sistem informasi (SI) antar bagian atau divisi. Data yang tidak terintegrasi memungkinkan adanya redudansi data, kekeliruan, kurangnya keakuratan data, dan kurang efisien dalam melaksanakan aktifitas. Diperlukan sebuah kerangka kerja dalam merencanakan, merancang, dan mengelola infrastruktur SI/TI yang disebut dengan Enterpise Architecture (EA). Perancangan berupa Administration System, Finance Management System, Human Resource dan Accounting. Data setiap sistem informasi sudah terintegrasi.
\end{abstract}

Kata Kunci: Enterprise Architecture, TOGAF

\section{PENDAHULUAN}

Perusahaan harus melakukan perencanaan yang matang ketika ingin memanfaatkan SI/TI dalam menjalankan bisnisnya. Perencanaan strategis SI/TI ini mutlak dilakukan oleh setiap perusahaan yang akan memanfaatkan SI/TI (Tambotoh, 2010)[1]. Hal ini karena perencanaan implementasi SI/TI harus diselaraskan antara strategi bisnis dan strategis teknologi (Ward dan Peppard, 2002)[2]. Sebagai kerangka untuk membuat keputusan TI jangka panjang yang tepat dengan mempertimbangkan kepentingan perusahaan secara keseluruhan, maka perusahaan harus merencanakan arsitektur TI. Suatu perusahaan dapat mengalami kekegalan dalam menerapkan SI/TI ketika kurang melakukan perencanaan yang matang dalam mengimplementasikan SI/TI. Masalah ini juga merupakan penyebab utama kegagagaln perusahaan dalam menerapkan SI/TI.

Untuk mengatasi masalah tersebut. sebuah kerangka kerja diperlukan dalam merencanakan, merancang, dan mengelola 
infrastruktur SI/TI. Enterpise Architecture merupakan salah kesatuan yang utuh dari prinsip, metode, dan model yang digunakan dalam perancangan dan realisasi struktur organisasi perusahaan, proses bisnis, sistem informasi, dan infrastruktur. Enterpise Architecture juga menggambarkan rencana untuk mengembangkan sebuah sistem atau sekumpulan sistem (Parizaue, 2002)[3].

Salah satu metode dalam merancang EA adalah melalui The Open Group Architecture Framework (TOGAF). TOGAF merupakan sebuah kerangka kerja arsitektur yang digunakan untuk merancang, mengevaluasi dan membangun arsitektur untuk sebuah organisasi. TOGAF dapat memberikan starting point dalam pembuatan arsitekturnya. Selain itu TOGAF juga bersifat open source dan sistematis.

CV. Agung Lestari merupakan perusahaan yang bergerak di bidang jasa pengurusan surat-surat kendaraan baru. Perusahaan ini memanfaatkan SI/TI dalam aktifitas yang dilakukan dan sudah memiliki aplikasi yang digunakan pada bagian administrasi. Namun, bagian keuangan dan akuntansi masih menggunakan aplikasi Microsoft Excel. Kondisi ini mengakibatkan tidak adanya integrasi data dan keterkaitan dengan sistem informasi (SI) antar divisi. Data yang tidak terintegrasi memungkinkan adanya redudansi data, kekeliruan dan kurangnya keakuratan data. Dengan demikian, agar terintergasi, efektif dan efisien perlu dibangun suatu arsitektur dengan framework tertentu sebagai solusi kebutuhan dari tiap bagian atau divisi.

Konsep SI/TI yang dapat digunakan dalam merencanakan SI/TI di CV. Agung Lastari adalah dengan membuat kerangka The Open Group Architecture Framework (TOGAF) dengan melakukan tahapan dalam Architecture Development Method (ADM). Tahapan yang ada pada TOGAF ADM juga dapat melakukan perencanaan SI/TI yang diselaraskan dengan perancangan arsitektur SI/TI. Kerangka kerja TOGAF dapat mencakup proses menyeluruh dari kebutuhan arsitektur bisnis, aplikasi dan infrastruktur. Selain itu, TOGAF juga dapat mendukung proses pembangunan kerangka arsitektur perusahaan dari tahap perencanaan arsitektur sampai tahap implementasi. Hal ini memiliki kesesuaian dengan kondisi CV. Agung Lestari yang belum memiliki enterprise architecture.

\section{METODE}

The Open Group Architecture Framework (TOGAF) digunakan sebagai acuan dalam tahapan penelitian. Pendekantan secara komprehensif untuk melakukan desain, perencanaan, implementasi dan tata kelola arsitektur sistem informasi dan teknologi informasi (SI/TI) organisasi diberikan oleh kerangka kerja TOGAF. 


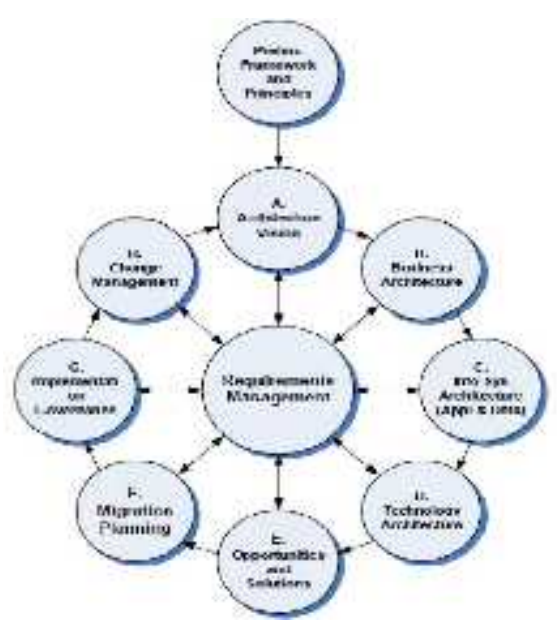

Gambar 1 Fase Architecture Devopment

\section{Method}

Beberapa tahapan dari TOGAF secara ringkas bisa dijelaskan sebagai berikut:

a. Architecture Vision

b. Business Architecture

c. Information System Architecture

d. Technology Architecture

e. Opportunities and Solution

f. Migration Planning

g. Implementation Governance

h. Architecture Change Management

(The Open Group, 2011)[4].

\section{HASIL DAN PEMBAHASAN}

\section{Architecture Vision}

Visi dari CV. Agung Lestari adalah "Menjadi Biro Jasa terbaik, terdepan, terpercaya dan unggul dalam layanan"

Untuk mewujudkan Visi, Maka ditetapkan misi dari Biro Jasa Agung Lestari adalah :
- Memberikan Pelayanan Pengurusan surat-surat kendaraan baik motor ataupun mobil.

- Memiliki team yang solid dan Personel lapangan yang berpengalaman.

- Melayani perorangan, Corporate/Perusahaan maupun Dealer.

CV. Agung Lestari memiliki beberapa tujuan untuk mendukung tercapainya Visi dan Misi.

1. Berkomintmen untuk selalu fokus dengan visi dan misi.

2. Konsisten untuk memberikan pelayanan sepenuh hati.

3. Memberikan pelayanan yang terbaik kepada semua customer.

4. Bekerjasama untuk menyelesaikan pekerjaan sesuai target.

\section{Businness Architecture}

Gambar 2 merupakan pemodelan use case diagram fungsi bisnis dan Stakeholder CV. Agung Lestari.

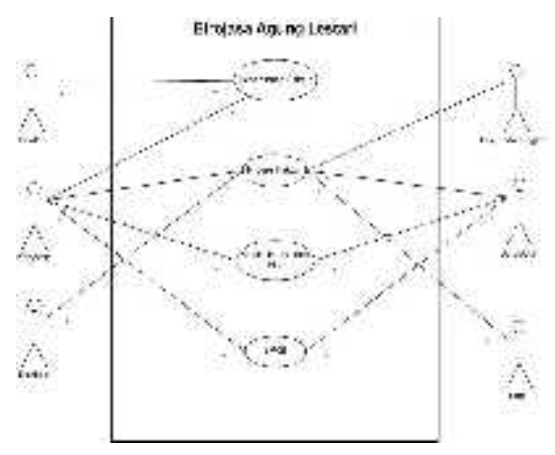

Gambar 2 Use Case Diagram Stakeholder CV. Agung Lestari 


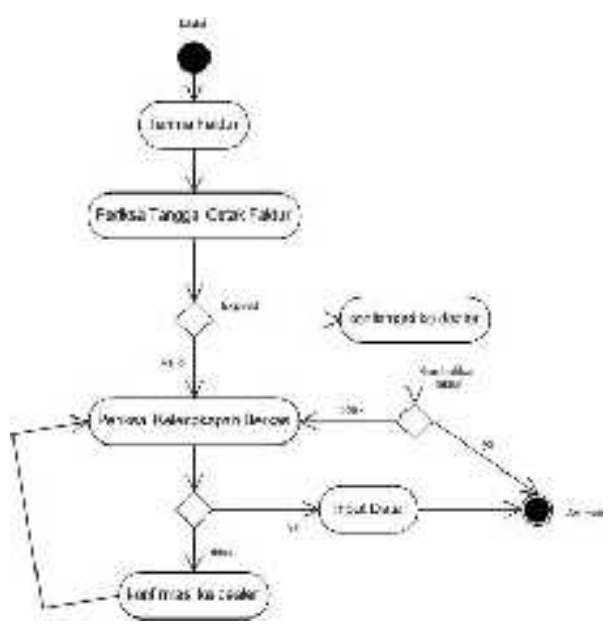

Gambar 3 Activity Diagram

Penerimaan Faktur dan Berkas

Pada aktivitas Penerimaan Faktur dan Berkas dilakukan pemerikasaan terhadap faktur dan berkas yang akan diproses. Aktivitas yang dilakukan :

- Memeriksa tanggal cetak faktur

- Memeriksa kelengkapan berkas

- $\quad$ Input data

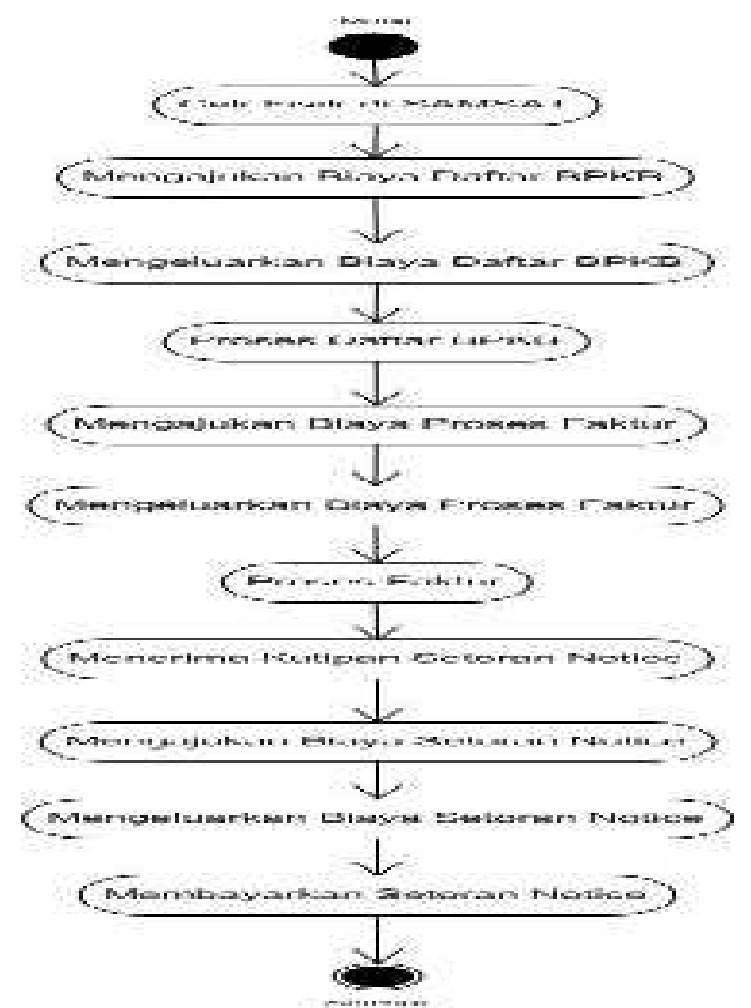

Gambar 4 Activity Diagram Proses Faktur
Pada aktivitas Proses Faktur dilakukan pemrosesan faktur unit kendaraan. Aktivitas yang dilakukan di SAMSAT:

- Cek Fisik

- Daftar BPKB

- Proses Faktur

- Pembayaran Setoran Notice

Aktivitas yang dilakukan di perusahaan :

- Mengajukan biaya daftar BPKB

- Mengeluarkan biaya daftar BPKB

- Mengajuakn biaya proses faktur

- Mengeluarkan biaya proses faktur

- Mengajukan biaya Setoran Notice

- Mengeluarkan biaya setoran notice

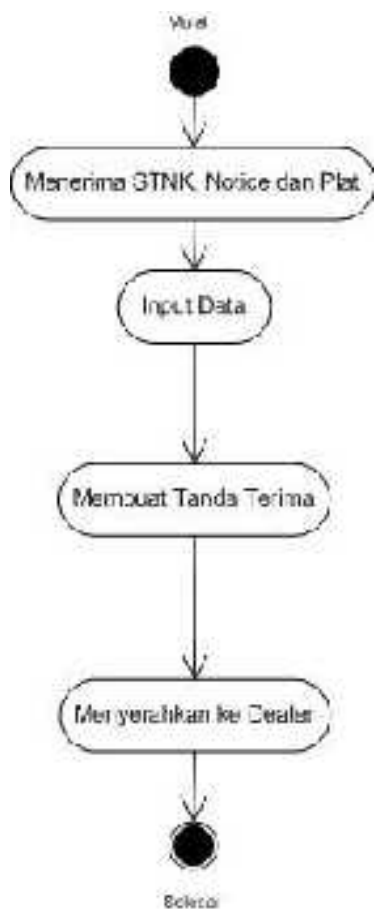

Gambar 5 Activity Diagram Penerimaan dan Penyerahan STNK, Notice dan Plat

Pada proses Penerimaan dan Penyerahan STNK, Notice dan Plat 
dilakukan penerimaan STNK, Notice, Plat dari SAMSAT dan penyerahan STNK, Notice, Plat ke dealer. Aktivitas yang dilakukan :

- Menerima STNK, Notice dan Plat

- Input data

- Membuat tanda terima

- Menyerahkan STNK, Notice dan Plat ke dealer

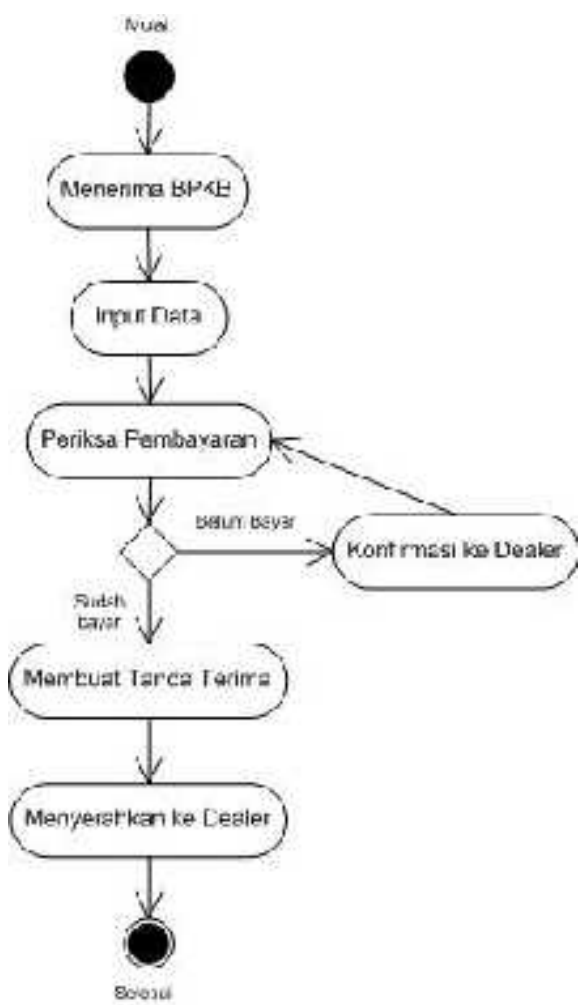

Gambar 6 Activity Diagram Penerimaan dan Penyerahan BPKB

Pada proses Penerimaan dan Penyerahan $\mathrm{BPKB}$

dilakukan penerimaan dan Penyerahan BPKB. Aktivitas yang dilakukan :

- Menerima BPKB

- Input data

- Memeriksa pembayaran
- Membuat tanda terima

- Menyerahkan ke dealer

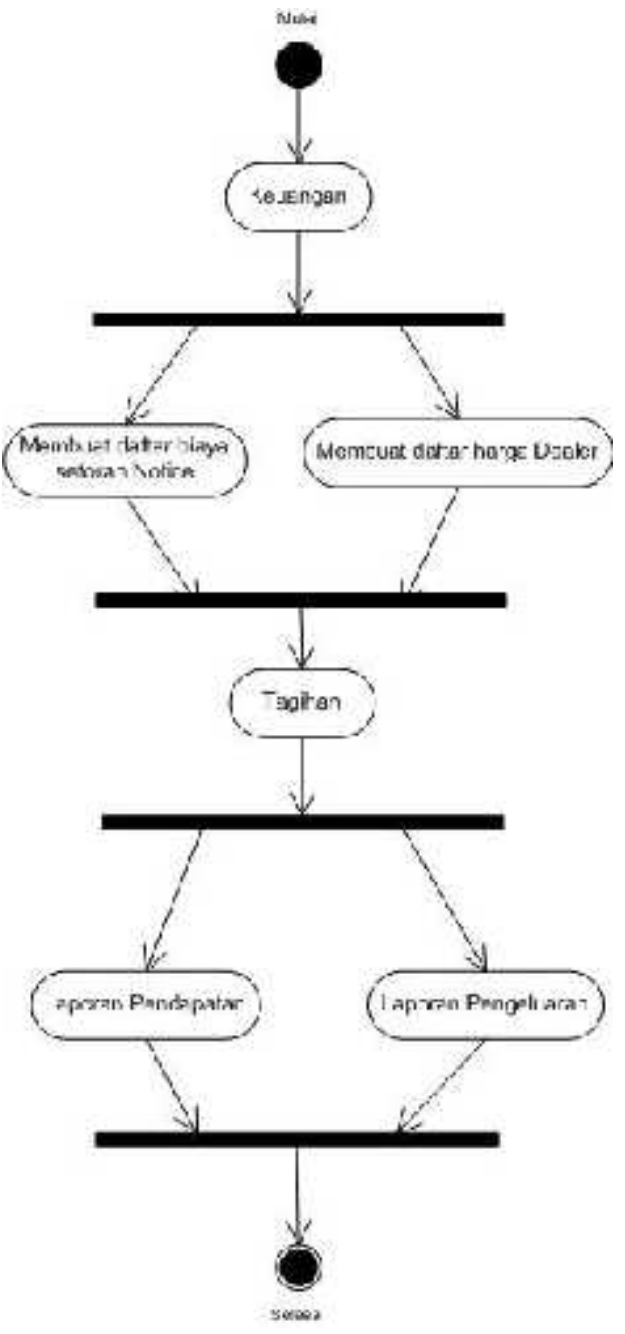

Gambar 7 Activity Diagram Keuangan

Gambar 7 merupakan pemodelan fungsi divisi Keuangan yang digambarkan menggunakan activity diagram.

Aktivitas yang dilakukan :

- Membuat daftar biaya setoran Notice

- Membuat daftar harga dealer

- Laporan pendapatan

- Laporan pengeluaran

- Membuat tagihan 


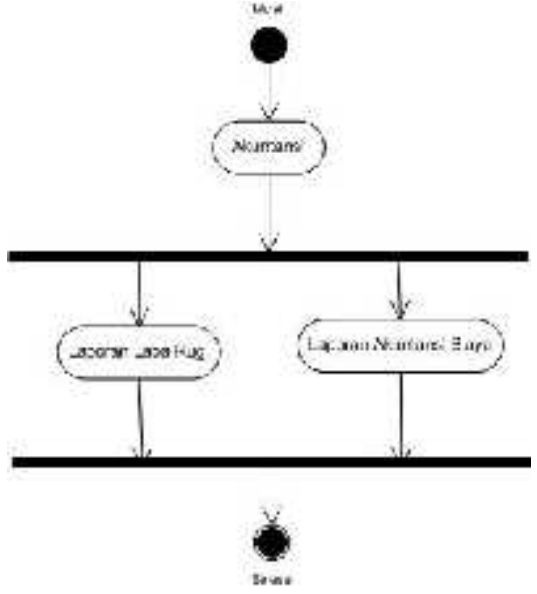

Gambar 8 Activity Diagram Akuntansi

Gambar 8 merupakan Pemodelan fungsi divisi Akuntansi yang digambarkan menggunakan activity diagram.

Akrivitas yang dilakukan :

- Laporan laba rugi

- Laporan akuntansi biaya

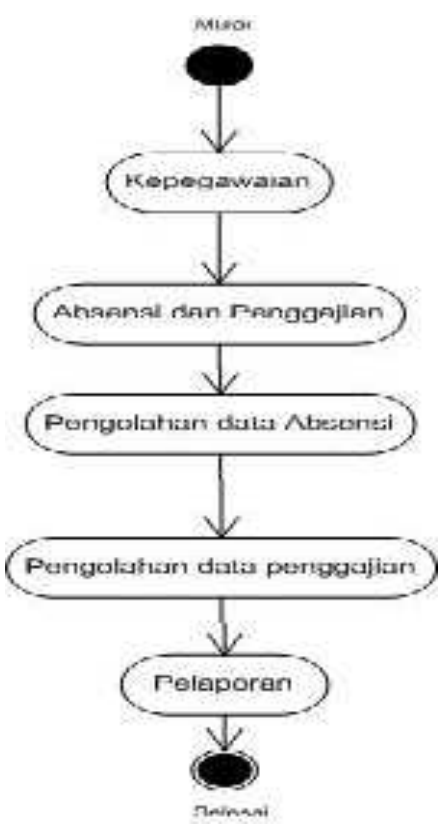

Gambar 9 Activity Diagram Kepegawaian Gambar 9 merupakan pemodelan fungsi divisi Kepegawaian yang digambarkan menggunakan activity diagram.
Aktivitas yang dilakukan :

- Absensi dan penggajian

- Pengolahan data absensi

- Pengolahan data Penggajian

- Laporan

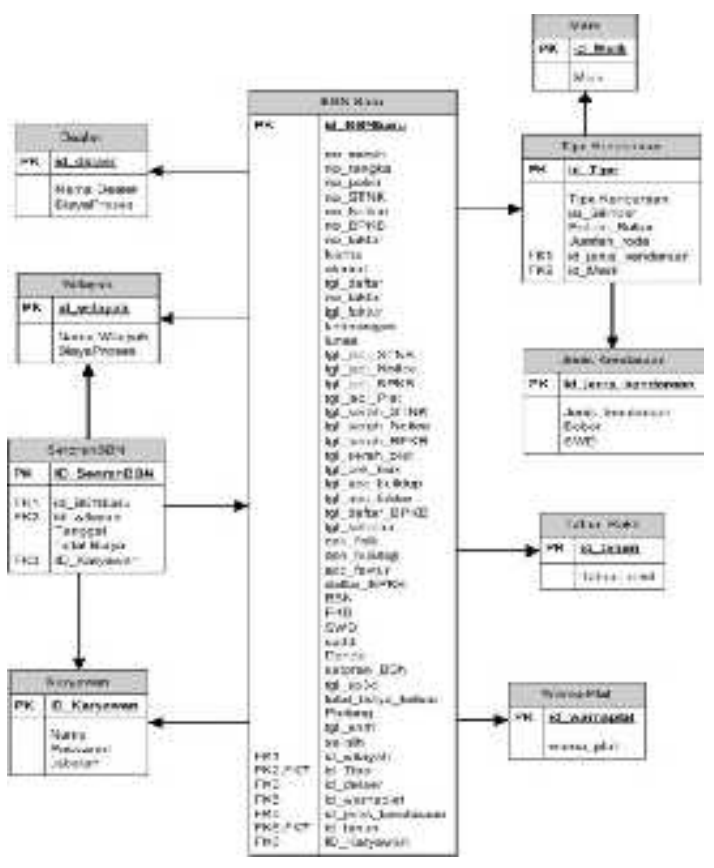

Gambar 10 Class diagram penerimaan faktur dan berkas

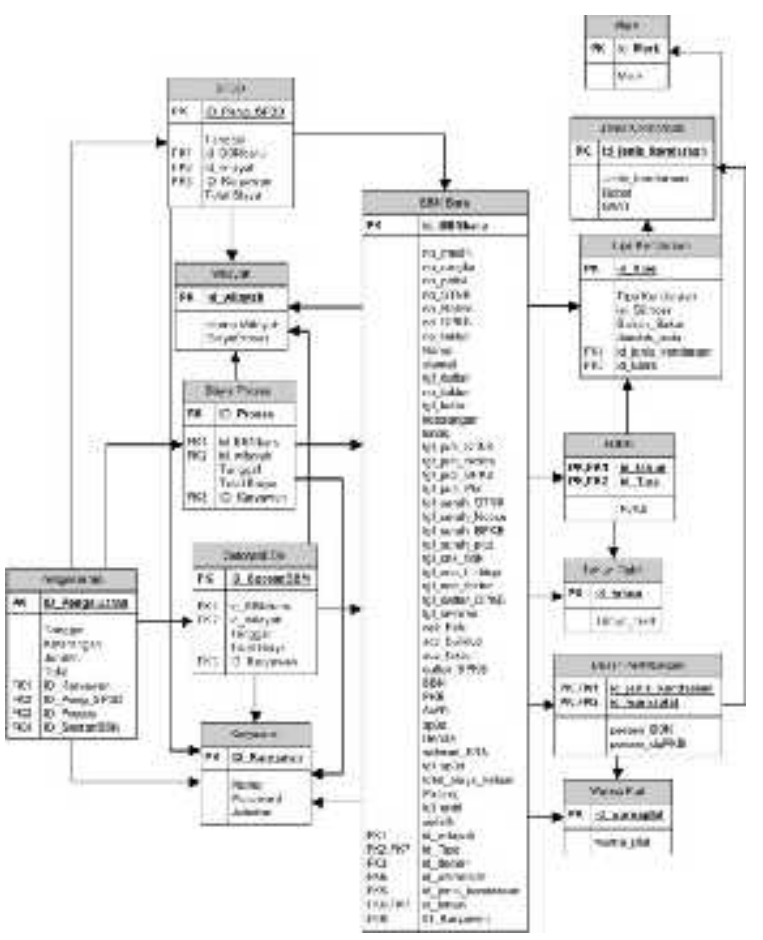

Gambar 11 Class diagram Proses faktur 


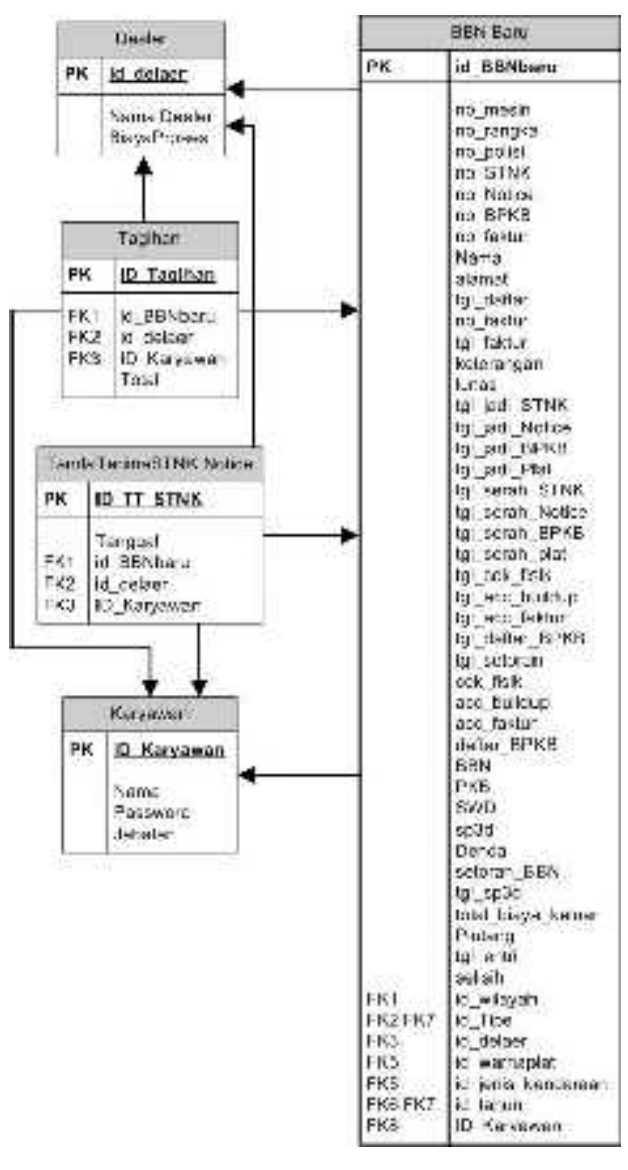

Gambar 12 Class diagram penerimaan dan penyerahan STNK, Notice dan Plat

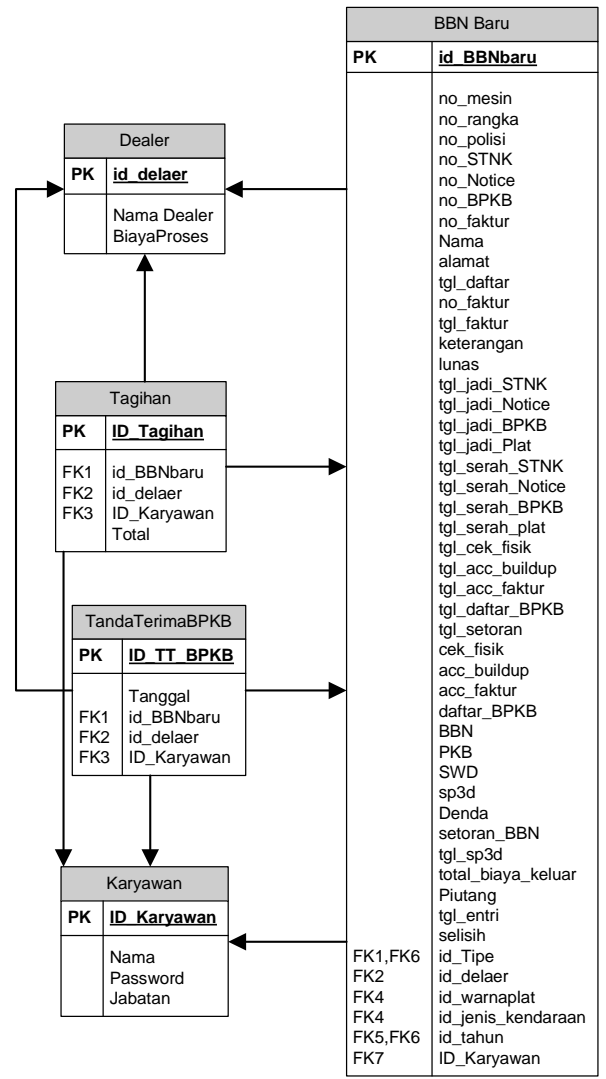

Gambar 13 Class diagram penerimaan dan penyerahan BPKB

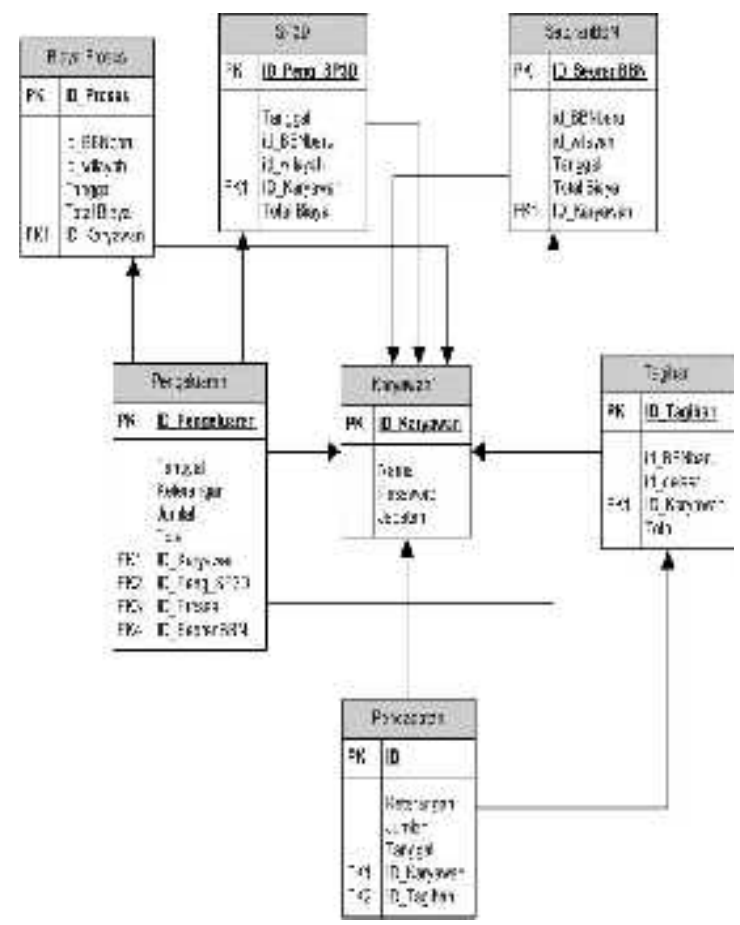

Gambar 14 Class diagram Keuangan 


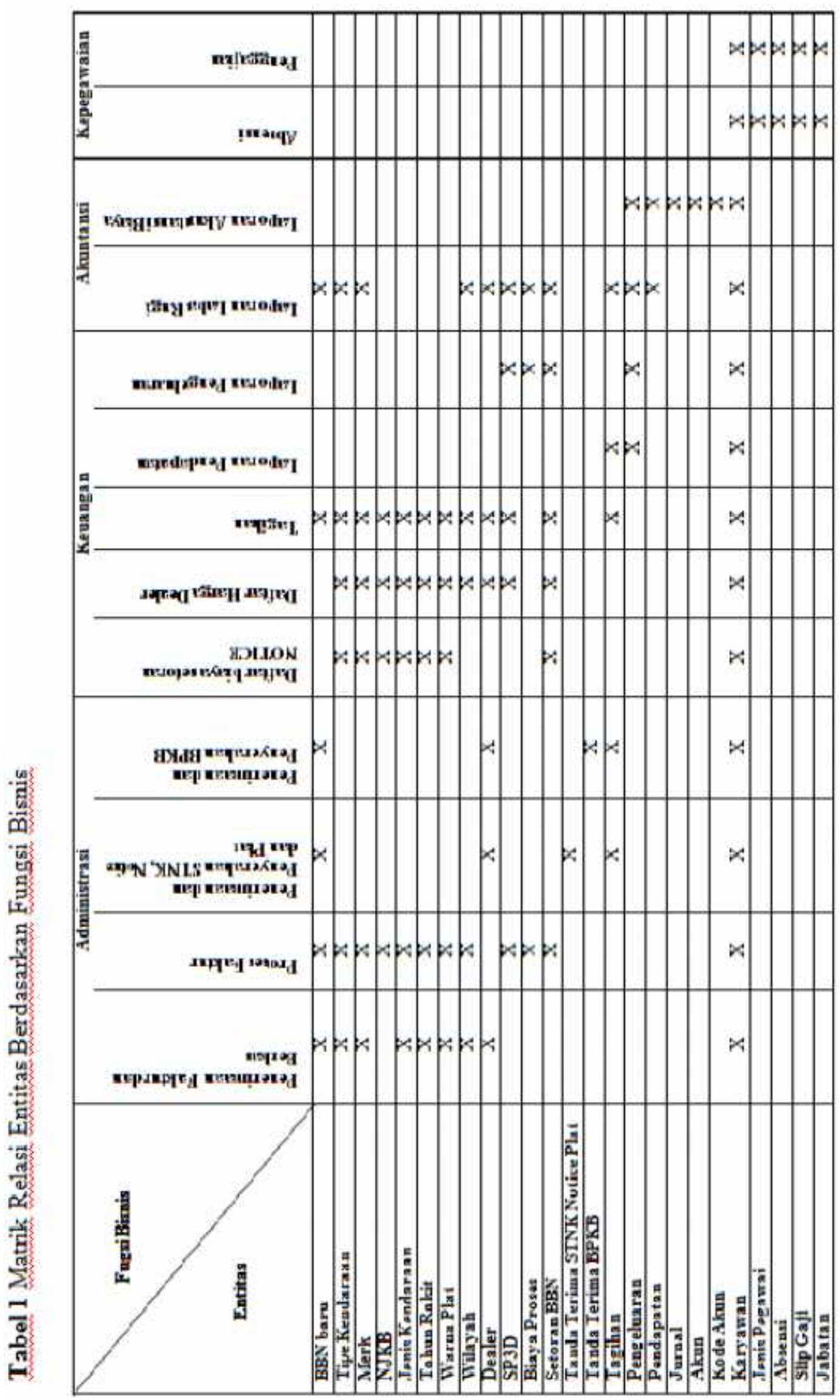




\section{Arsitektur Aplikasi}

Identifikasi Arsitektur aplikasi berdasarkan pada :

- Kebutuhan pertukaran informasi antar fungsi bisnis.

- Kebutuhan informasi yang digunakan untuk mendukung pengambilan keputusan disetiap fungsi bisnis.

- Kebutuhan alat bantu di setiap fungsi bisnis.

Solusi aplikasi untuk CV. Agung Lestari terlihat pada gambar 17 .

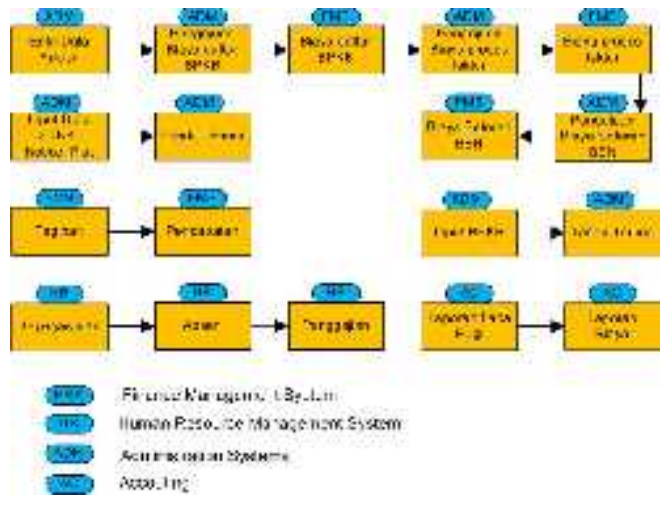

Gambar 17 Solusi Aplikasi

Application Portofolio CV. Agung Lestari terlihat pada tabel 2 .

Tabel 2 Application Portofolio

\begin{tabular}{|c|l|l|}
\hline Kode & Nama & Fungsi \\
\hline ADM & $\begin{array}{l}\text { Administration } \\
\text { Systems }\end{array}$ & $\begin{array}{l}\text { Entri data faktur, } \\
\text { Pengajuan biaya } \\
\text { daftar BPKB, } \\
\end{array}$ \\
& & $\begin{array}{l}\text { Pengajuan biaya } \\
\text { proses faktur, } \\
\text { Pengajuan biaya } \\
\text { setoran BBN, } \\
\end{array}$ \\
& & $\begin{array}{l}\text { Input data STNK, } \\
\text { Input data Notice, } \\
\text { Input data plat, } \\
\end{array}$ \\
& & $\begin{array}{l}\text { Input data BPKB, } \\
\text { Tanda Terima }\end{array}$ \\
\hline FMS & $\begin{array}{l}\text { Finance } \\
\text { Management }\end{array}$ & $\begin{array}{l}\text { Pengeluaran, } \\
\text { Tagihan, }\end{array}$ \\
\hline
\end{tabular}

\begin{tabular}{|c|l|l|}
\hline & System & Pendapatan \\
\hline $\mathrm{AC}$ & Accounting & $\begin{array}{l}\text { Jurnal, Laporan } \\
\text { Laba rugi }\end{array}$ \\
\hline $\mathrm{HR}$ & $\begin{array}{l}\text { Human Resource } \\
\text { Management } \\
\text { System }\end{array}$ & $\begin{array}{l}\text { Kepegawaian, } \\
\text { Absen, } \\
\text { Penggajian }\end{array}$ \\
\hline
\end{tabular}

Untuk menggambarkan hubungan

antar sistem aplikasi dapat dimodelkan menggunakan Application Landscape yang terlihat pada gambar 18.

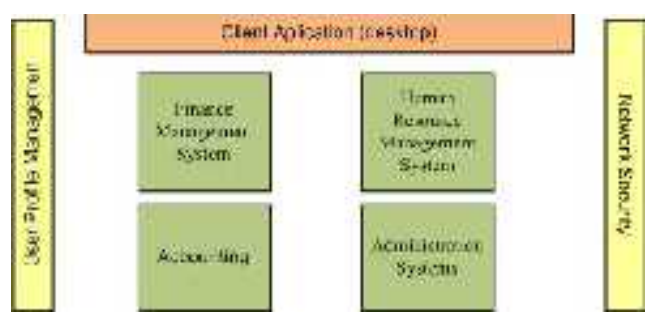

Gambar 18 Application Landscape

Proses pemetaan terhadap komponen infrastruktur berdasarkan arsitektur sistem informasi terlihat pada gambar 19.

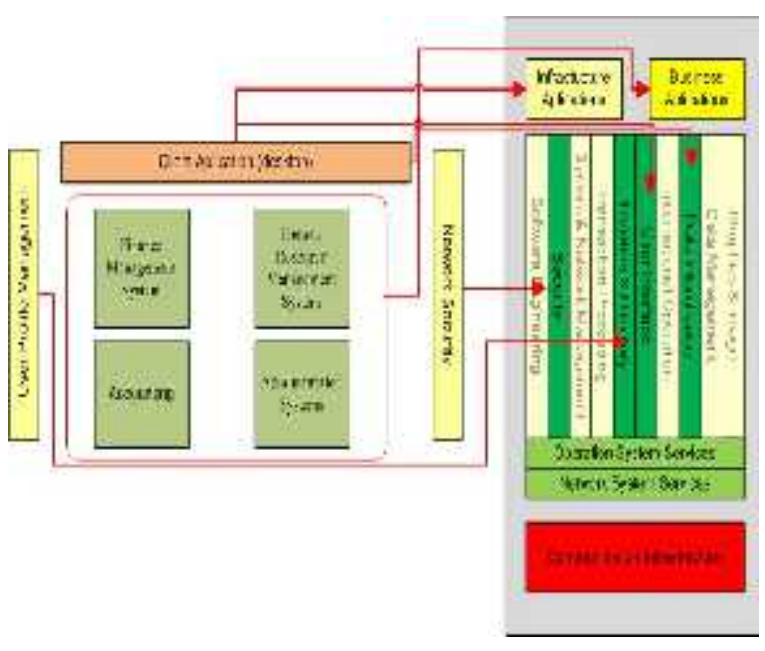

Gambar 19 Mapping to Generic

Architecture

Gambar 20 merupakan pemetaan arsitektur sistem aplikasi dengan arsitektur 
teknologi yang menggunakan komponen infrastruktur.

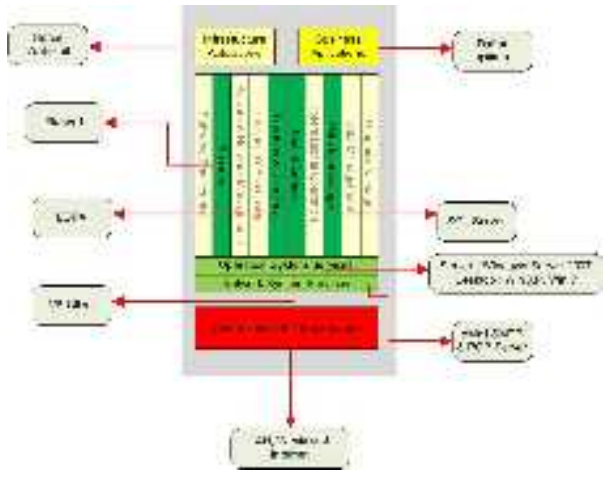

Gambar 20 Foundation Architecture

Berdasarkan pemetaan arsitektur sistem aplikasi terhadap arsitektur teknologi dan mengacu kepada komponen infrastruktur yang digunakan dalam pemetaan, maka dapat dibuat arsitektur secara keseluruhan terlihat pada gambar 21.

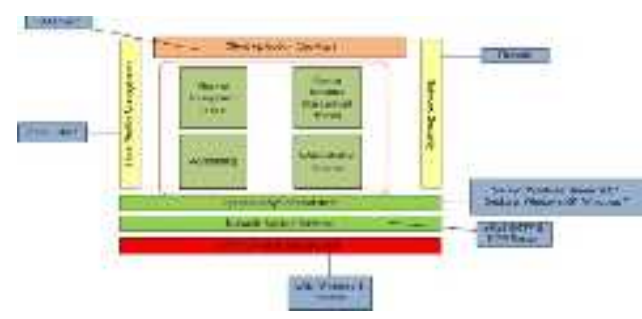

Gambar 21 Overall Architecture

Gambar 21 merupakan arsitektur secara keseluruhan. Kategori yang digunakan sebagai berikut :

- Infrastructure Application

Infrastructure Application terdiri dari database server.

- Business Application
Business Application merupakan aplikasi yang dibutuhkan yang terdiri dari tiga aplikasi.

- Spesifikasi komponen

- User Interface

User Interface berbasis Graphical User Interface menggunakan VB.

- Location and Directory

Layanan untuk mencari sumber informasi yang diperlukan.

- Security

Layanan untuk melindungi data dan informasi dalam sistem informasi.

- Operating System

- Server : Windows Server 2007

- Desktop : Windows 7 dan Windows $\mathrm{XP}$

- Network Services

Layanan yang memberikan akses ke data dan modifikasi data.

- Communication Infrastructure Infrastruktur jaringan yang terdiri dari Local Area Network, Wireless Network dan Internet .

\section{Technology Architecture}

Pada gambar 22 dapat dilihat proses transformasi informasi antara sistem aplikasi dan aliran informasi antara sistem aplikasi. 


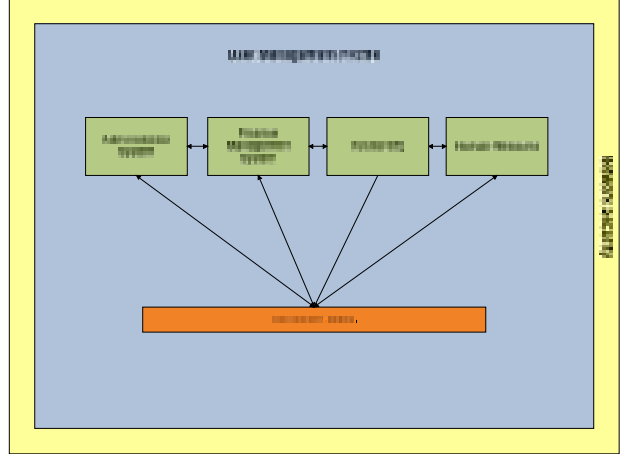

Gambar 22 Aliran Informasi antar sistem

Platform aplikasi dapat dilihat pada gambar 23.

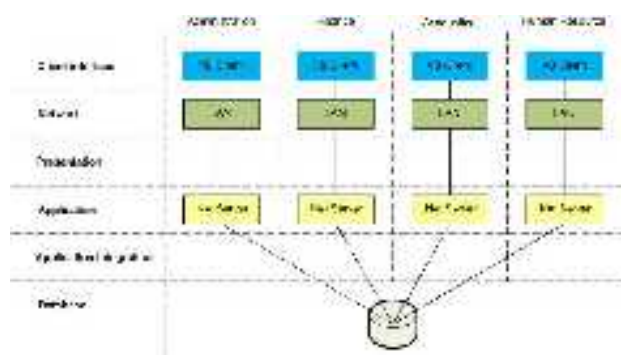

Gambar 23 Application Platform

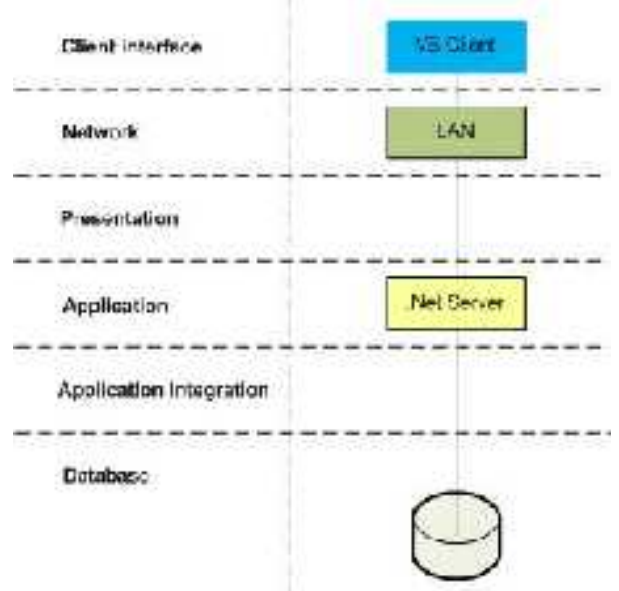

Gambar 24 Unified Application Platform

Infrastruktur jaringan CV. Agung Lestari dapat dilihat pada gambar 25 . Topologi yang digunakan adalah topologi Star. Topologi ini menggunakan switch untuk menghubungkan client dengan client yang lainnya. Penggunaan topologi Star memiliki beberapa kelibihan yaitu dinamis, client yang mengalami gangguan tidak mempengaruhi kinerja jaringan, mudah dalam pemeliharaan dan keamanan yang cukup baik.

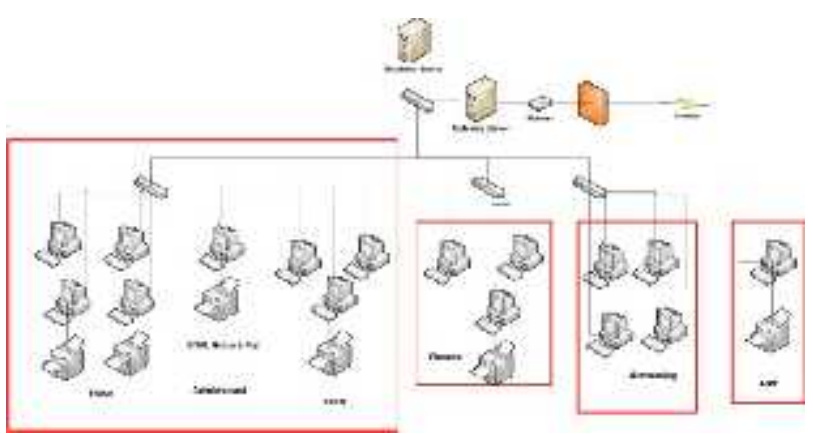

Gambar 25 Infrastructure Topology

\section{Opportunities and Solution}

Gap Sistem Informasi

menggambarkan kondisi sistem informasi saat ini dengan yang akan datang, dapat dilihat pada tabel 3 .

Tabel 3 Gap Sistem Informasi

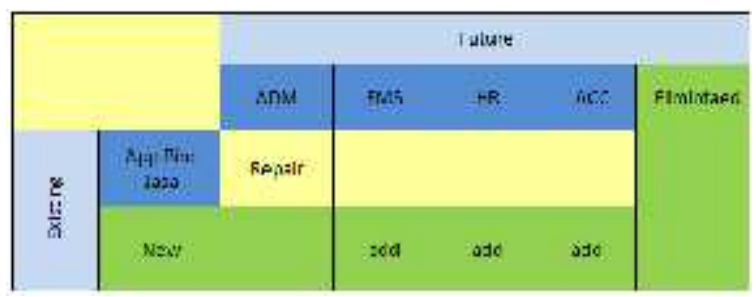

Tabel 4 Gap Teknologi

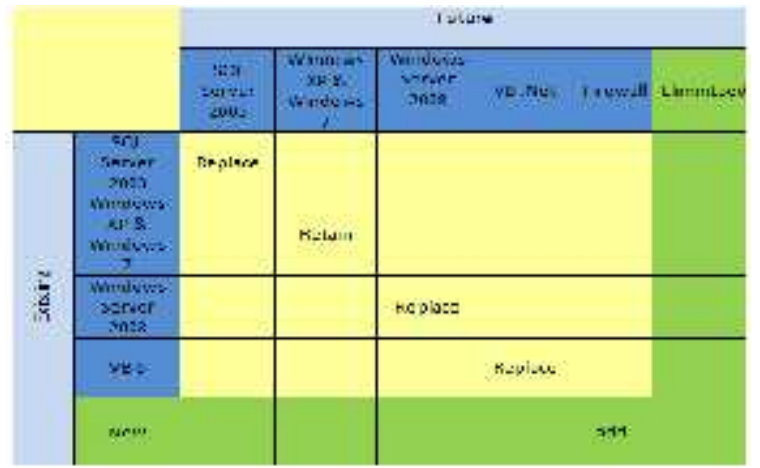


Migration Planning

Penilaian dalam menentukan rencana migrasi dari suatu sistem informasi dilakukan pada tahap ini. Migrasi sistem memiliki resiko apabila sistem dianggap gagal dalam mendukung bisnis perusahaan. Sebelum melakukan migrasi, harus dilakukan tahap ujicoba dalam penggunaannya. Tabel 5 merupakan rencana teknis migrasi sistem lama ke sistem baru. Table 4.12 berisi rumusan resiko yang mungkin terjadi dan solusi saat rencana migrasi ke sistem baru.

Tabel 5 Rencana Teknis

\begin{tabular}{|l|l|l|}
\hline No. & \multicolumn{1}{|c|}{ Tahapan } & \multicolumn{1}{|c|}{ Requirement } \\
\hline 1. & $\begin{array}{l}\text { Back-up database } \\
\text { sistem lama }\end{array}$ & $\begin{array}{l}\text { Database Aplikasi } \\
\text { Biro Jasa }\end{array}$ \\
\hline 2 & $\begin{array}{l}\text { Install dan } \\
\text { konfigurasi sistem } \\
\text { baru }\end{array}$ & $\begin{array}{l}\text { Install perangkat } \\
\text { lunak yang } \\
\text { diperlukan untuk } \\
\text { mendukung sistem } \\
\text { baru }\end{array}$ \\
\hline 3 & $\begin{array}{l}\text { Import database } \\
\text { lama ke database } \\
\text { baru }\end{array}$ & $\begin{array}{l}\text { Databse } \\
\text { Administrasi }\end{array}$ \\
\hline 4 & $\begin{array}{l}\text { Masukan data-data } \\
\text { yang diperlukan } \\
\text { pada database baru }\end{array}$ & $\begin{array}{l}\text { Data NJKB, biaya- } \\
\text { biaya untuk proses } \\
\text { faktur kendaraan, } \\
\text { biaya-biaya yang } \\
\text { ditagihkan ke dealer }\end{array}$ \\
\hline 5 & $\begin{array}{l}\text { Jalankan sistem } \\
\text { baru }\end{array}$ & $\begin{array}{l}\text { Periksa fitur dan } \\
\text { keakuratan data }\end{array}$ \\
\hline
\end{tabular}

Tabel 6 Resiko

\begin{tabular}{|l|l|l|l|}
\hline No & Factor & Description & Impact \\
\hline 1 & $\begin{array}{l}\text { Pergantian } \\
\text { Sistem } \\
\text { Informasi }\end{array}$ & $\begin{array}{l}\text { Pergantian } \\
\text { ke sistem } \\
\text { informasi } \\
\text { baru }\end{array}$ & $\begin{array}{l}\text { Proses bisnis } \\
\text { terhambat } \\
\text { karena sistem } \\
\text { informasi di } \\
\text { non-aktifkan. }\end{array}$ \\
\hline 2 & $\begin{array}{l}\text { Kesalahan } \\
\text { dalam } \\
\text { penggunaan } \\
\text { sistem }\end{array}$ & $\begin{array}{l}\text { Bug dalam } \\
\text { sistem } \\
\text { informasi }\end{array}$ & $\begin{array}{l}\text { Sistem tidak } \\
\text { berjalan } \\
\text { dengan } \\
\text { semestinya }\end{array}$ \\
\hline
\end{tabular}

\begin{tabular}{|l|l|l|l|}
\hline & informasi & $\begin{array}{l}\text { menyebabkan } \\
\text { proses bisnis } \\
\text { terhambat }\end{array}$ \\
\hline 3 & $\begin{array}{l}\text { PC \& } \\
\text { Server }\end{array}$ & $\begin{array}{l}\text { Spesifikasi } \\
\text { PC atau } \\
\text { Server } \\
\text { kurang } \\
\text { memenuhi } \\
\text { kebutuhan } \\
\text { untuk } \\
\text { menjalakan } \\
\text { sistem } \\
\text { informasi }\end{array}$ & $\begin{array}{l}\text { Performa } \\
\text { sistem } \\
\text { berjalan } \\
\text { lambat } \\
\text { menyebabkan } \\
\text { proses bisnis } \\
\text { terhambat }\end{array}$ \\
\hline 4 & User & $\begin{array}{l}\text { User belum } \\
\text { mengerti } \\
\text { sistem } \\
\text { informasi } \\
\text { baru }\end{array}$ & $\begin{array}{l}\text { User masih } \\
\text { beradaptasi } \\
\text { dengan } \\
\text { sistem baru } \\
\text { menyebabkan } \\
\text { proses bisnis } \\
\text { terhambat } \\
\text { karena. }\end{array}$ \\
\hline
\end{tabular}

\section{Impementation Governance}

Pada tahap ini dilakukan penyusunan rekomendasi untuk pelaksanaan tata kelola implementasi sistem yang sudah dilakukan, meliputi tata kelola organisasi dan tata kelola teknologi.

Tata kelola Organisasi meliputi :

1. Pendefinisian Visi dan Misi

2. Penyusunan Organisasi
a. Direktur
b. Kepala Administrasi
c. Kepala Finance
d. Kepala Akunting
e. Staff Pelaksana

Tata kelola teknologi meliputi :

- Semua fungsi sistem informasi dapat diakses di PC Direktur .

- Setiap PC hanya dapat mengakses aplikasi sesuai divisi. 
- Database Server diletakan di ruangan tersendiri untuk menjaga keamanan data.

\section{Change management}

Masalah-masalah akan timbul ketika enterprise architecture diterapkan. Sebagian muncul dari user, dimana user perlu melakukan adaptasi dengan sistem baru. Perubahan pada tingkat personal mengubah perilaku pegawai dengan cara pemusatan keterampilan, pengharapan, sikap dan persepsi mereka akan melakasanakan tugas lebih efisien. Perubahan pada tingkat organisasi bertujuan untuk melakukan perubahan budaya organisasi dan perubahan struktur organisasi. Perubahan pada proses pekerjaan, metode-metode dan perlengkapan organisasi merupakan tujuan dari perubahan dari sisi teknologi.

Tabel 7 Tabel Perubahan

\begin{tabular}{|c|c|c|}
\hline No. & Proses & Perubahan \\
\hline 1 & Finance & $\begin{array}{l}\text { Perubahan cara } \\
\text { pembuatan tagihan } \\
\text { yang sebelumnya } \\
\text { menggunakan excel } \\
\text { dan memasukan harga } \\
\text { setoran per-unit } \\
\text { kendaran, menjadi } \\
\text { menggunakan Finance } \\
\text { Management system. }\end{array}$ \\
\hline 2 & Akuntansi & $\begin{array}{l}\text { Sebelumnya } \\
\text { menggunakan excel, } \\
\text { menjadi menggunakan } \\
\text { Accounting } \\
\text { Management System. }\end{array}$ \\
\hline 3 & $\begin{array}{l}\text { Human } \\
\text { Resource }\end{array}$ & $\begin{array}{l}\text { Sebelumnya } \\
\text { menggunakan excel } \\
\text { untuk absensi dan }\end{array}$ \\
\hline
\end{tabular}

\begin{tabular}{|c|l|l|}
\hline & & $\begin{array}{l}\text { penggajian, menjadi } \\
\text { menggunakan Human } \\
\text { Resource Management } \\
\text { System. }\end{array}$ \\
\hline 4 & Administrasi & $\begin{array}{l}\text { Sebelumnya } \\
\text { menggunakan aplikasi } \\
\text { Biro Jasa, menjadi } \\
\text { menggunakan } \\
\text { Administration System. }\end{array}$ \\
\hline
\end{tabular}

\section{SIMPULAN}

Berdasarkan hasil pembahasan dan analisis pada perancangan arsitektur enterprise di CV. Agung Lestari, maka dapat ditarik kesimpulan, yaitu:

- Pemodelan bisnis yang dikelola oleh CV. Agung Lestari memiliki aktivitas utama dan aktivitas pendukung. Aktivitas utama yaitu administrasi, meliputi penerimaan faktur dan berkas, proses faktur, penerimaan dan penyerahan STNK, Notice, Plat dan BPKB. Sedangkan aktivitas pendukung sebagai penopang aktivitas utama meliputi Finance, Accounting dan Human Resource.

- Hasil perancangan berupa Administration System, Finance Management System, Human Resource dan Accounting. Data setiap sistem informasi sudah terintegrasi.

- Pengelolaan SI/TI di CV. Agung Lestari dapat menggunakan Enterprise Architecture yang sudah terbentuk. 


\section{Daftar Pustaka}

Tambotoh, J., (2010), Penerapan Kajian Kelayakan Finansial intuk Meningkatkan Tingkat Kematangan Managemen Investasi Sistem Informasi/Teknologi Informasi Studi Kasus : PT. PLN(Persero), Jakarta: Universitas Indonesia. Thesis.

Ward, J., Peppard, J., (2002), Strategic Planning for Information Systems 3rd Ed., UK: John Wiley \& Sons, Ltd.

Parizeau, Y., (2002), Enterprise Architecture for Complex Government and the Challage of Government On-line in Canada Dalhoussie University. Canada : Dalhousie University

The Open Group, (2011), Open Group Standard, United Kingdom. 